\title{
The Supercharging Effect on the Performance and Emission of Diesel Engine Fueled with Tyre Pyrolysis Oil and Diesel Blend
}

\author{
Mukesh N Damor ${ }^{1,}$ Yuvrajsinh Raol ${ }^{2}$, Tushar M Patel ${ }^{3}$ and Gaurav P Rathod ${ }^{4}$ \\ ${ }^{1}$ M.E. IC/Auto Student, L.C. Institute of Technology, Bhandu \\ ${ }^{2}$ Assistant professor, Mechanical Engineering Dept., L.C.I.T, Bhandu \\ ${ }^{3}$ Associate professor, Mechanical Engineering Dept., L. D. R. P-ITR, Gandhinagar \\ ${ }^{4}$ Assistant Professor, Mechanical Engineering Dept., L. D. R. P-ITR, Gandhinagar
}

\begin{abstract}
The price was going up day to day and there will be no more conventional fuel in the future and also increasing the environmental pollution by the use of crude oil. Therefore, research has focused on finding new alternative fuel and utilizes them for the automotive application. We were taking Pyrolysis oil from waste tyre and blended with diesel fuel. In the initial stage we were performing this test will conduct on a single cylinder, four- stroke, constant speed water cooled, diesel engine by using only diesel and results are observed for 1 to 9 load condition. In experiment were being carried out on the same engine with same operation parameter with using the tyre pyrolysis oil blended with diesel in different proportion such as TP10, TP20, TP30 at supercharging pressure 1.5 bar and result will be compared.
\end{abstract}

Keywords: - Diesel engine, pyrolysis oil, supercharging, Engine Emission

\section{INTRODUCTION}

Our demand for energy is increasing every day may of the common forms of energy are fossil fuel, The increasing population on the earth caused over increasing demands of energy. If the scrap tires are not managed well, the scrap tire can give bad effects to the environment and people's health. The uncontrolled open waste tire fires on water and air is a major concern because they release potentially hazardous levels of carbon monoxide and mono and poly aromatic hydrocarbon in the smoke plume. Land filling of waste tire requires more land area. Waste tire dump and stockpiles through the entrapment of rain water, can in certain climate conditions, become suitable for inserts, like mosquitoes, capable of transmitting disease to humans. The solution of their dumping is pyrolysis process. Pyrolysis oil is made by this process. Before this is needed for survey on various alternative fuels used in diesel engine by various researches. Sk.Mohammad Younus et al conduct experiment investigation were carried out single cylinder diesel engine by using pyrolysis oil blended with diesel and ethanol was added $0.5 \%$ and $1 \%$ to blend percentage emission are decreased when compared to neat diesel [1].

S.Murugan et al carried out to evaluate the performance and emission characteristic of single cylinder direct injection diesel engine fuelled by 10\%, 30\% and 50\% blend of tyre pyrolysis oil(TPO) with diesel fuel (DF).Result showed that the brake thermal efficiency of the engine fueled by TPO-DF blend increasing with increasing in blended concentration and higher than diesel .NOx, HC, CO and Smoke emission were found to be higher at higher load [2,3]. M. Man et al conducted performance tests on diesel engine by using waste plastic oil as alternate field. The experimental results have shown stable performance with a brake "thermal efficiency similar to that of diesel. Carbon dioxide and unburned hydrocarbons were marginally higher than that of the diesel baseline. The toxic gas $\mathrm{CO}$ emission of waste plastic oil was higher than diesel. Smoke reduced by about $40 \%$ to $50 \%$ using waste plastic oil at all loads [4].G.V.N Kumar et al carried out to experimental investigation on single cylinder 4-stroke diesel engine direct injection by using pyrolysis oil blend in the sense of incensed brake thermal efficiency, decreased brake specific fuel consumption and decreased emission like smoke density, unburned hydrocarbon and carbon monoxide [5].

From the literature, it is concluded that fuels can be used as a substitute for diesel and blending them with diesel proportional can improve performance parameter and reduce emission and also using supercharging to improve performance parameter and reduce exhaust gas emission.

\subsection{Introduction to Supercharging:-}

The power and efficiency Of an internal combustion engine are increasing with increasing compression ratio, speed of engine, charge density and reducing exhaust temperature. Supercharging in internal combustion engine is one of the methods to improving engine performance and efficiency. The Supercharger can be defined as the process of increasing charge (inlet Air) density in order to increase power output and efficiency of the engine the purpose of supercharging an engine is to raise the density of the air charge, before it's delivered to the cylinder. Thus, the increasing mass of air trapped and then compressed in each cylinder during each 
induction and compression stroke make more oxygen available for combustion than the conventional method of drawing the fresh air charge into the cylinder [8]

A supercharger is a device that the pressure of the air intake to above atmospheric pressure. Supercharger increases intake mass by compressing air above atmospheric pressure with the help of a compressor A Supercharger is a compressor used to increase in pressure and density of air supplied to an internal combustion engine. This compressor air supply a greater mass of oxygen per cycle of the engine. The supercharger has driven mechanically by belt, chain drive or buys gear from the engine's crankshaft. Most of the supercharger drives by boat.

\subsection{Introduction to Pyrolysis oil:-}

Pyrolysis is a thermo chemical decomposition of organic material at elevated temperatures without the participation of oxygen. It involves the simultaneous change of chemical composition and physical phase, and is irreversible. The word is coined from the Greek -derived elements Pyr "fire" and lysis "separating"[7].

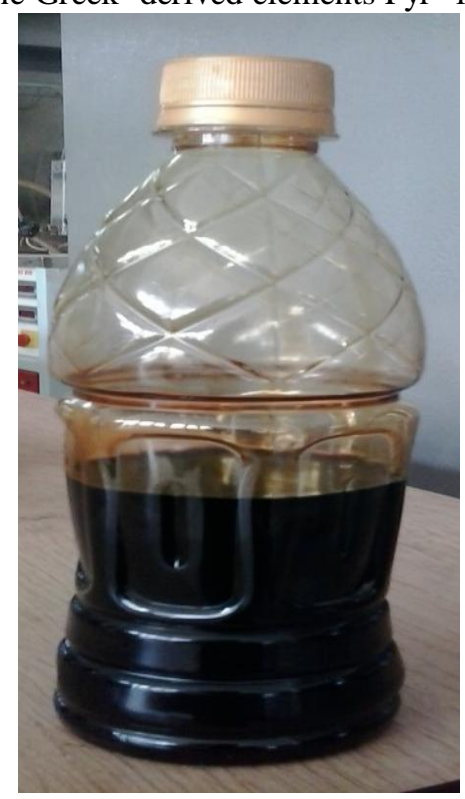

Fig.1 Pyrolysis oil

In regards to the pyrolysis of tires, the tires are reduced primarily into three products. Carbon black, fuel oil, steel (the steel belt in the tire) and other hydrocarbon gases. Pyrolysis gas can be condensed recovering pyrolysis oil. The recovered oil usually has a specific gravity about 0.93 , a sulfur content $1.1 \%$ as well as residual carbon contains. This oil can be further filtered prior, to be used mainly a heating oil or commonly named LFO. Its kinematic viscosity is 2.6 cents-stokes (CST) which make in non-viscous liquid [6].

\section{PROPERTIES OF TYRE PYROLYSIS AND DIESEL FUEL}

Table.1 Property of tyre pyrolysis oil

\begin{tabular}{|c|c|c|}
\hline Properties & Diesel oil & Pyrolysis oil \\
\hline Density kg/m $\mathrm{m}^{3}$ & 0.830 & 0.923 \\
\hline Kinematic Viscosity cst @ 40 C & 2.58 & 3.77 \\
\hline Calorific value $(\mathrm{mj} / \mathrm{kg})$ & 43.8 & 38 \\
\hline Sulfur contains & $1.2 \%$ & $0.06 \%$ \\
\hline Ash content\% & 0.01 & 0.72 \\
\hline Flash point, $\mathrm{C}^{\circ}$ & 50 & 43 \\
\hline
\end{tabular}

\section{EXPERIMENTAL SETUP AND TECHNICAL METHOD}

\subsection{Experimental Setup}

Experiments were carried out with single cylinder, four strokes and water cooled, multi fuel research engine. 


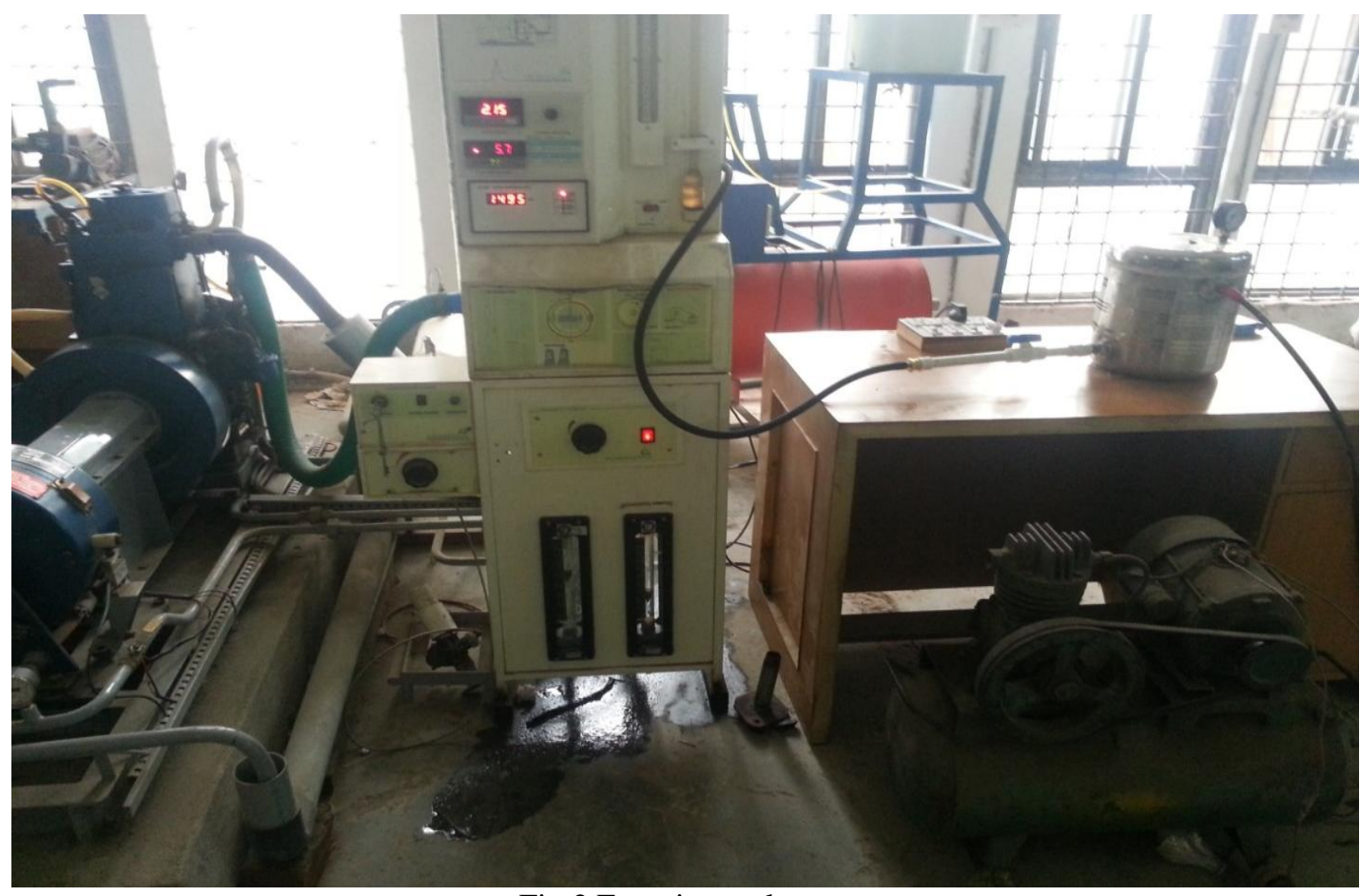

Fig.2 Experimental setup

Experiments were carried out with single cylinder, four strokes and water cooled, multi fuel research engine. Table 2. And fig. 2 shows the engine specification and engine setup respectively. The engine was run at constant speed $1500 \mathrm{rpm}$ and the measure brake torque the engine is connected to eddy current type dynamometer for loading. Before starting experiments load cell is calibrated accurately.

Table.2 Engine specifications

\begin{tabular}{|l|l|}
\hline Engine manufacturer & Apex Innovations (Research Engine test setup) \\
\hline Engine type & Single cylinder, four stroke multi fuel research engine \\
\hline Number of cylinders & One \\
\hline Types of cooling & Water cooling \\
\hline Rated power & $3.5 \mathrm{~kW}$ at $1500 \mathrm{RPM}$ \\
\hline Bore/stroke & $87.5 / 110 \mathrm{~mm}$ \\
\hline Dynamometer & Eddy current Type water cooled with loading unit \\
\hline
\end{tabular}

3.2Arrangements used for supercharging.

3.2.1 Compressor drives by external source of the power.

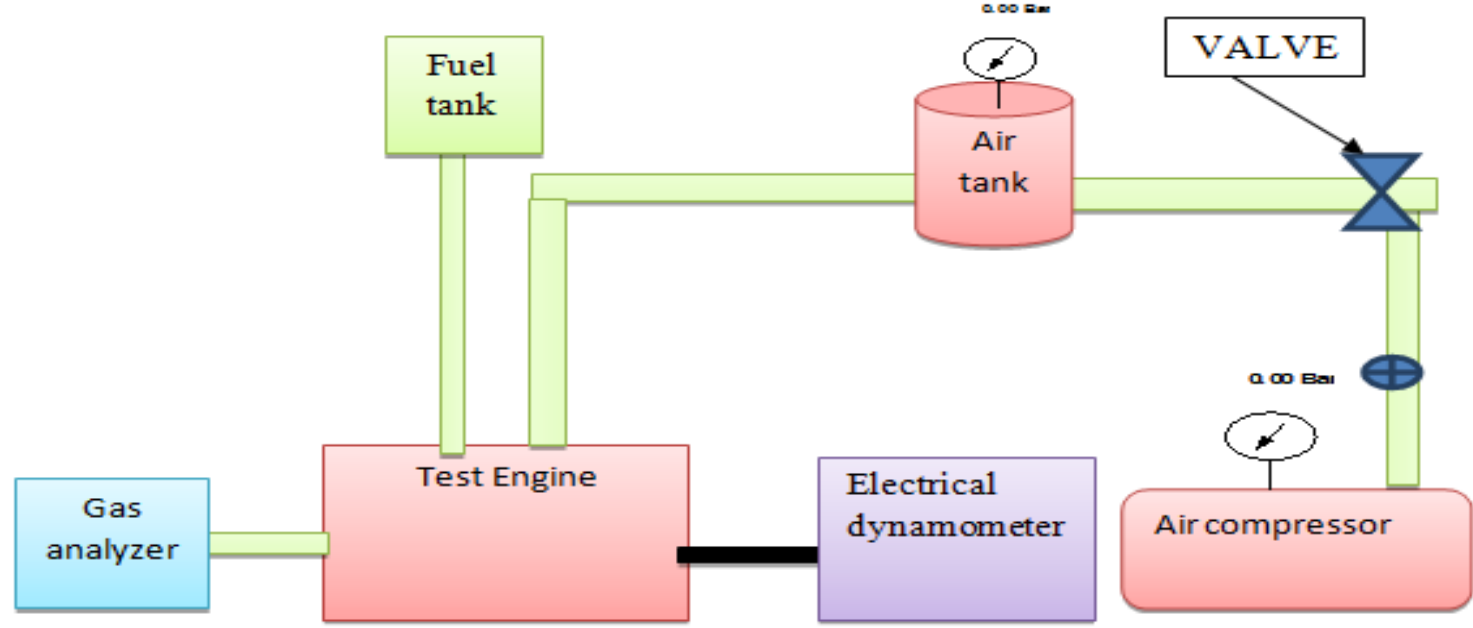

Fig. 3 Schematic diagram of arrangements of the supercharging 
In this arrangement, the compressor (supercharger) is separately driven by External power source (electric motor) as shown in fig.3 The compressor is used to increasing an air pressure but the flow of air is not continuous so Air box method is used to continuous air flow rate in our engine. An air tank is connected at the intake of the engine. A water manometer in used to measure the pressure difference between atmosphere and air box.

\subsection{Exhaust Gas Analyzer:-}

In this study QUATTRO PRO, GA4040 type gas analyzer was used so as to measure exhausts emission before It use in experiments device was calibrated. Exhaust gas analyzer is used to measure the level of pollutants in the exhaust of the car.

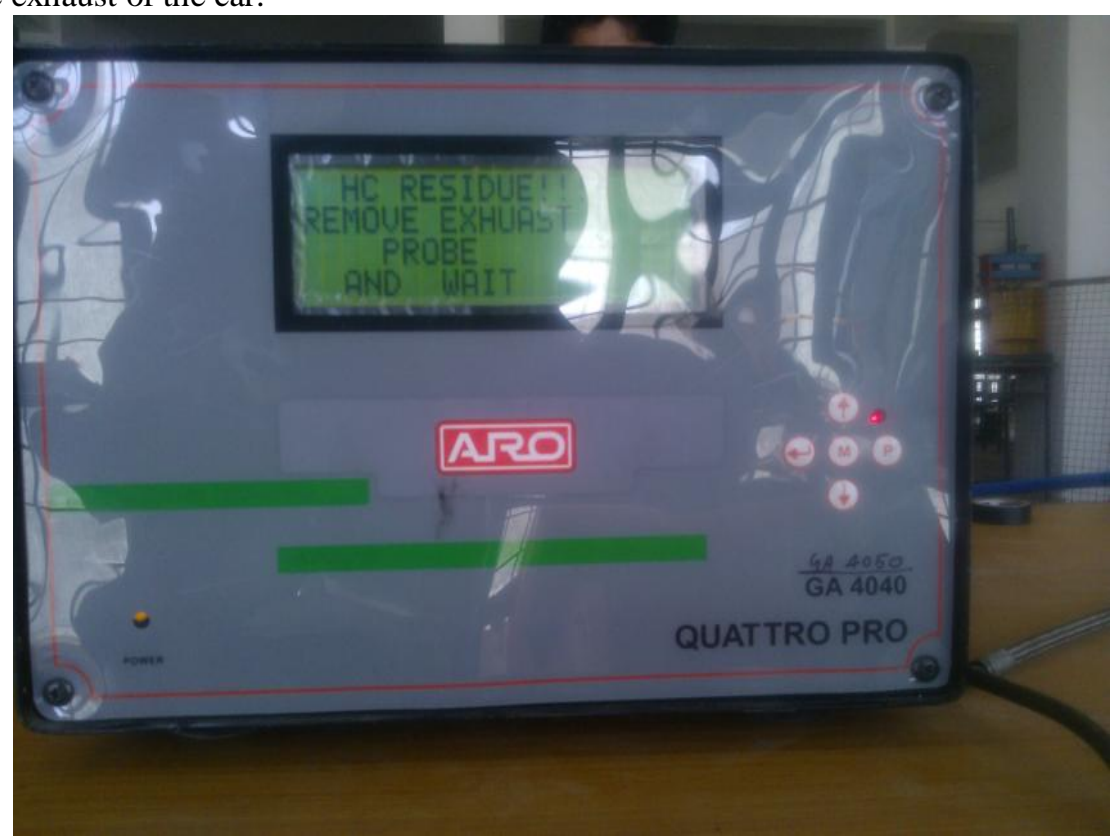

Fig. 4 Exhaust gas analyzer

\section{RESULTS AND DISCUSSION}

4.1 Comparisons of performance and Exhaust Emission of engine using Different blend with 1.5 bar supercharging.

4.1.1Fuel consumption: Shows the fig.5 the variation of fuel consumption with brake power at various blend proportion in the diesel.

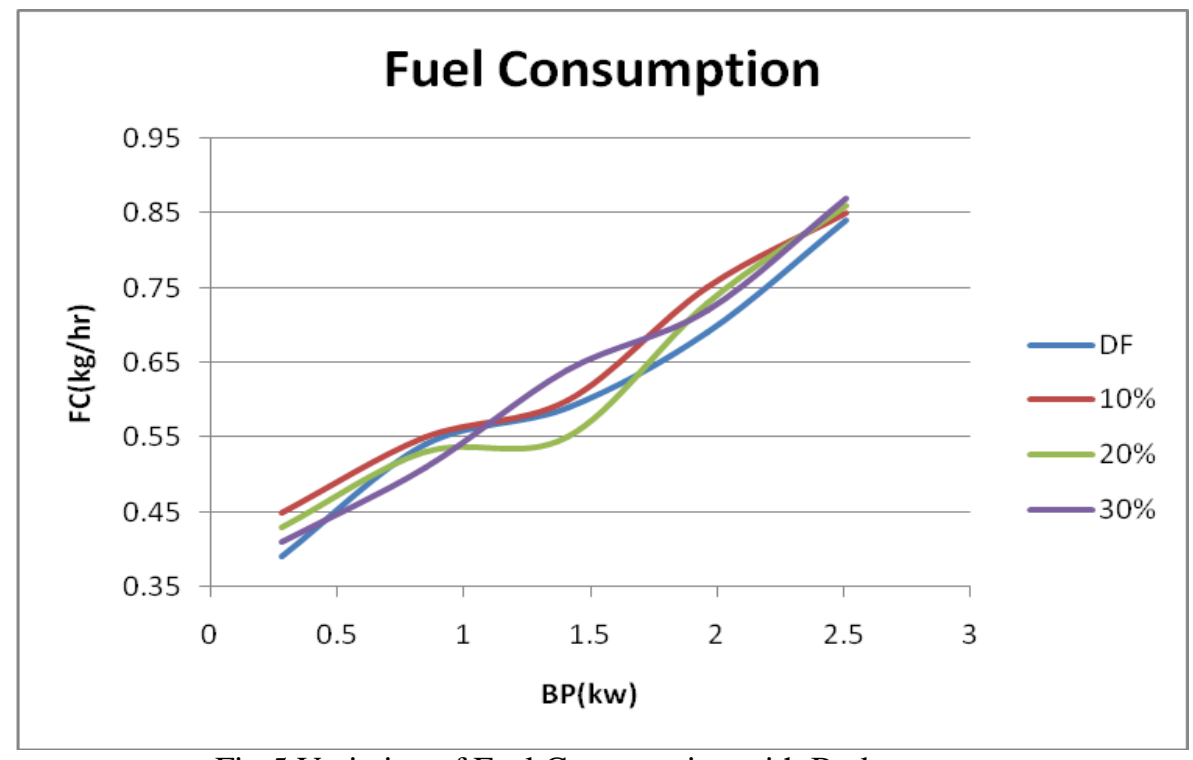

Fig.5 Variation of Fuel Consumption with Brake power 
The fuel consumption varies with engine power. The fuel consumption increase with increase brake power. pyrolysis oil from waste automobile tyre is added as a blended fuel in proportion of $10 \%, 20 \%, 30 \%$. There is an increase in fuel consumption found with increase in brake power but as concentration of pyrolysis oil in Diesel-pyrolysis blend increase ,the fuel consumption found deceased with load compared to Diesel fuel

\subsubsection{Specific Fuel consumption:}

Fig.6 shows the variation of specific fuel consumption with brake power at various blend proportion in the diesel.

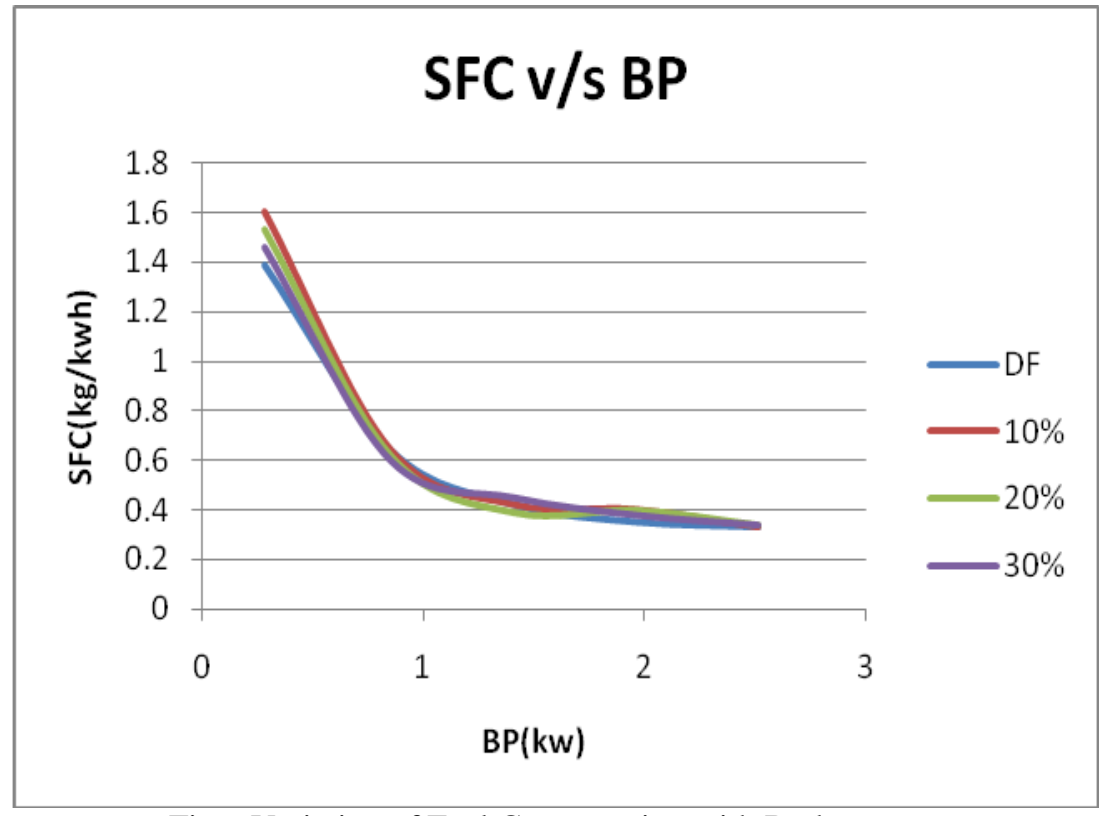

Fig.6 Variation of Fuel Consumption with Brake power

The Specific fuel consumption varies with engine power The Specific fuel consumption decrease with increase engine power but is increase compared to Diesel fuel because more fuel required producing the same power by diesel fuel, The Specific fuel consumption of D70 P30 found lower compared D90 P10 and D80 P20 but found higher compared to DF.

\subsubsection{Mechanical Efficiency:}

Fig. 7 shows the variation of Mechanical Efficiency with brake power at various blend proportion in the diesel.

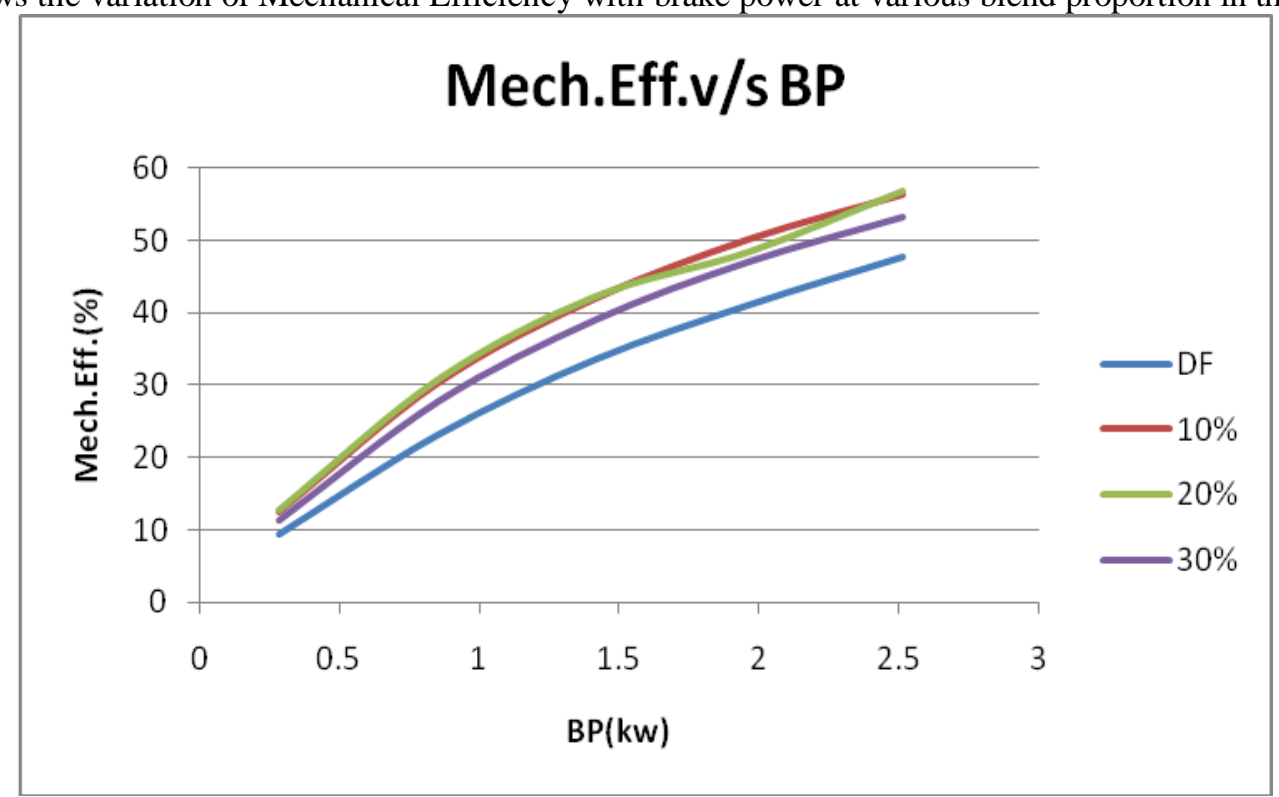

Fig.7 Mechanical Efficiency with Brake power 
In Diesel-pyrolysis oil blend, The Mechanical Efficiency varies with engine power, The Mechanical Efficiency Diesel-Pyrolysis oil blend is higher compared to Diesel fuel, D80 P20 found higher mechanical Efficiency compared to D90 P10, D70 P30 and Diesel fuel.

\subsection{4: Carbon Monoxide Emission:}

Fig.8 shows the variation of Carbon monoxide Emission with brake power at various blend proportion in the diesel.

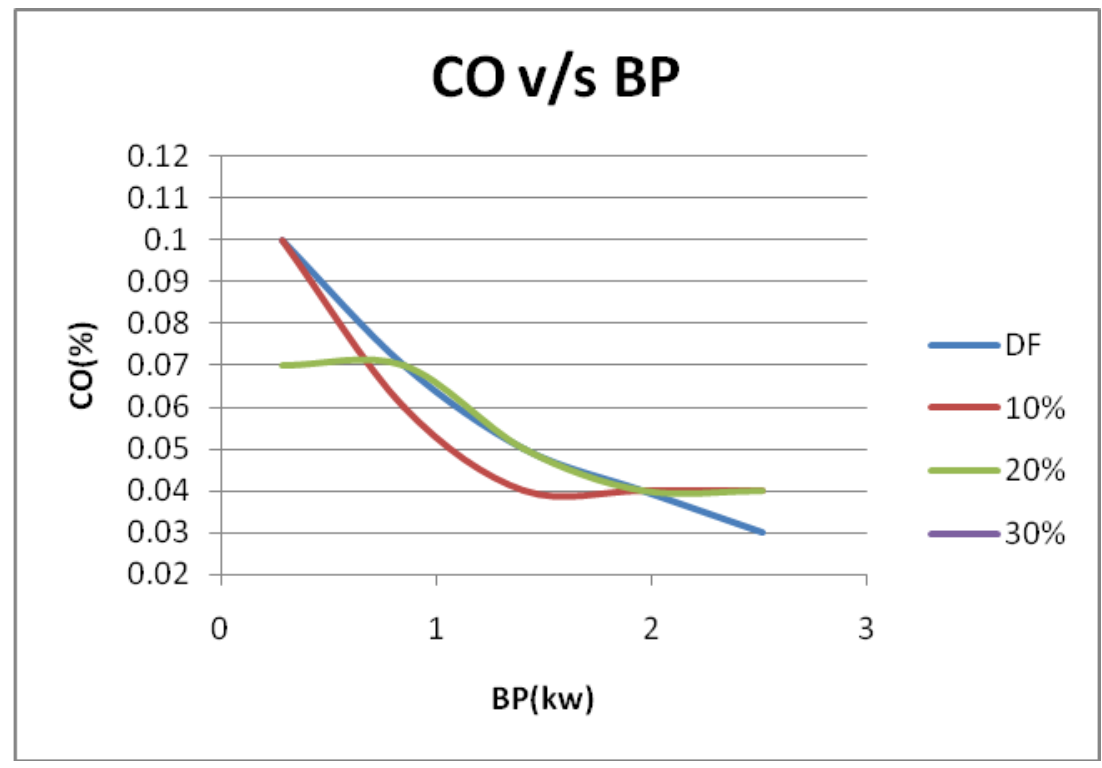

Fig.8 Carbon monoxide Emission Vs Brake power

The Variation of Carbon Monoxide (CO) Emission with Brake power is show in fig.8, The Carbon monoxide Emission are Comparatively no more difference with Diesel fuel but Slightly Decreased with increased load.

\subsection{5: Unburned Hydrocarbons Emission:}

Fig.9 shows the variation of Unburned hydrocarbon Emission with brake power at various blend proportion in the diesel.

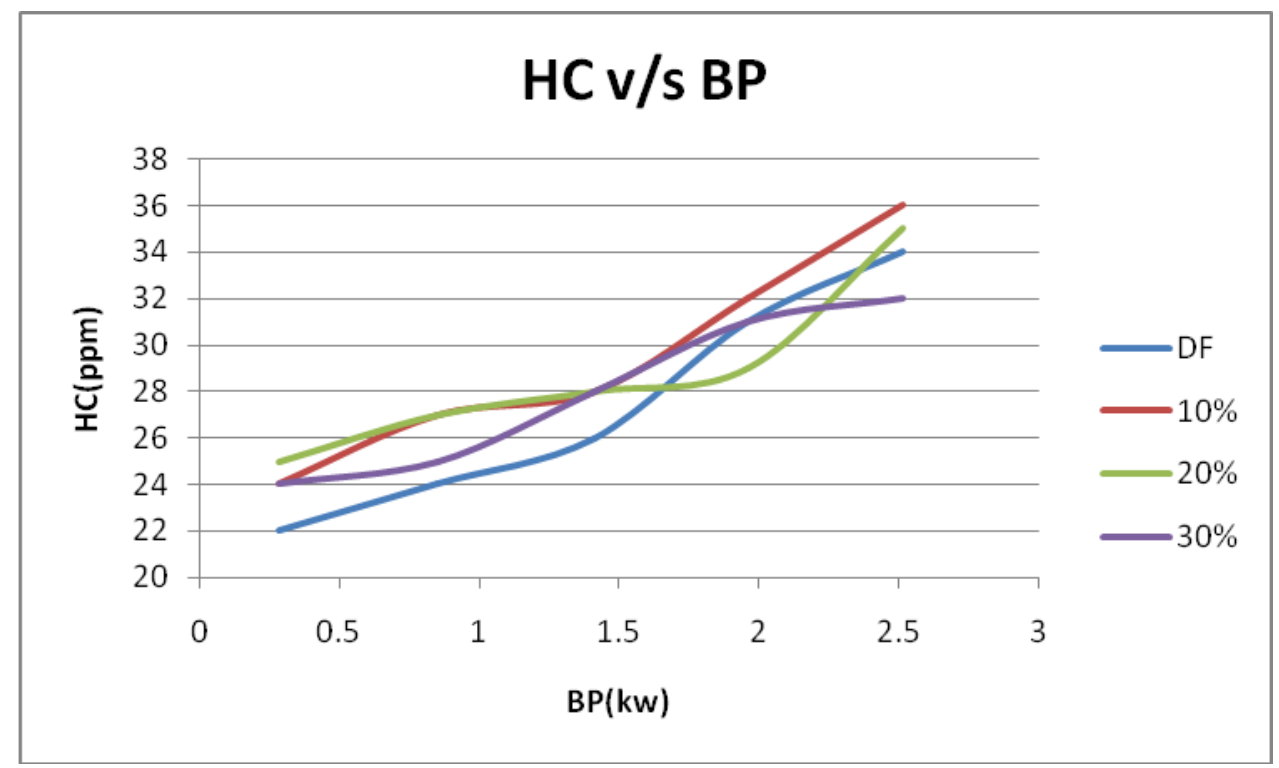

Fig.9 Unburned Hydrocarbon Vs Brake power

Fig.9 Shows the variation of HC with Brake power. As the Concentration of tyre pyrolysis oil Diesel blend increased HC Compared to diesel. HC of D70 P30 found lower compared D90 P10 and D80 P20 but found higher compared to DF. 


\subsection{6: Nitrogen Oxide (NOx) Emission:}

Fig.10 shows the variation of Unburned hydrocarbon Emission with brake power at various blend proportion in the diesel.

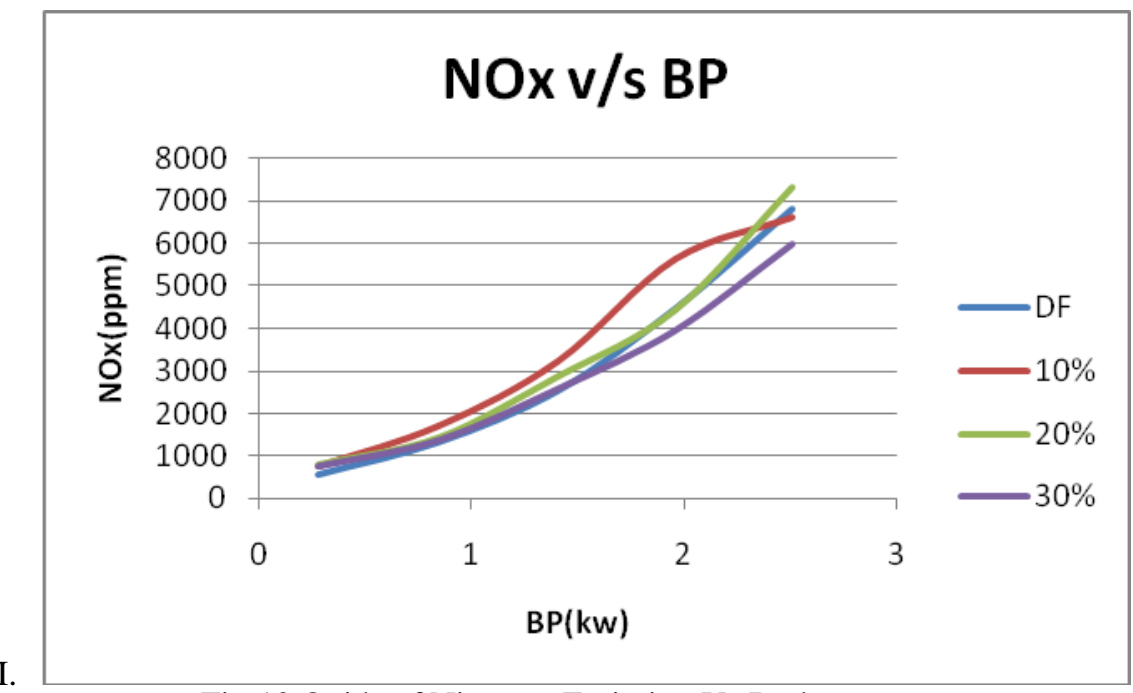

Fig.10 Oxide of Nitrogen Emission Vs Brake power

The Variation of NOx emission with Brake power is shows fig.10 The Nitrogen oxide Emission increased with the increased engine load due to temperature in the combustion chamber,D70 P30 found decreased nitrogen oxide compared to D90 P10, D80 P20 and Diesel fuel.

\section{CONCLUSION}

The conclusion derive from present experimental investigation to evaluate performance and exhaust gas emission on four stroke single cylinder diesel engine fueled with diesel - tyre pyrolysis oil blend.

- Brake thermal efficiency increased with all blends when compared to the conventional diesel fuel.

- The specific fuel consumption is decreased with the blends when compared to diesel fuel

- Carbon Monoxide, carbon dioxide, and unburned hydrocarbon are decreased significantly with the blend when compared with diesel fuel.

- From the above analysis the blend D70 P30 Show the better performance to other blend (D90 P10,D80 P20) and diesel.

- it observed With an increase in supercharging pressure, the performance of the engine is gradually improving

\section{NOMENCLATURE}

SFC Specific Fuel Consumption

TH Thermal Efficiency

CO Carbon Monoxide

HC Unburned Hydrocarbon

NOx Oxide of Nitrogen

PPM Part per million

D90 P10 Diesel 90\% Tyre Pyrolysis oil 10\%

D80 P20 Diesel 80\% Tyre Pyrolysis oil 20\%

D70 P10 Diesel 70\% Tyre Pyrolysis oil 30\%

\section{ACKNOWLEDGEMENTS}

The authors are highly grateful to LDRP-ITR to provide lab facility. They are also thankful to staff of LDRPITR, Gandhinagar.

\section{REFERENCES}

[1] Sk.Mohammad Younus, "Performance and Emissions Characteristics of Diesel Engine Fueled With Tyre Pyrolysis Oil \&Diesel Blends with Additives." International Journal of Engineering Science Invention, Volume 2 ,issue 5/may/2013/pp.32-37

[2] S. Murugan , M.C. Ramaswamy and G. Nagarajan "The use of tyre pyrolysis oil in diesel engines" waste management volume 29 issue 12 December 2008 page 2743-2749 
[3] Sivalingam MURUGAN, M. R. Chandrasekaran RAMASWAMY, and Govindan NAGARAJAN "influence of distillation on performance, emission, and combustion of a DI diesel engine, using tyre" Thermal science volume 12(2008)/pp.157-167

[4] M. Mani, "Performance, emission and combustion characteristics of a DI diesel engine using waste plastic oil" Applied Thermal science, Volume 29, issue 2009/pp.2738-2744.

[5] G.V.N KUMAR, "Experimental Investigations on Diesel Engine Fueled with Tyre Pyrolysis Oil and Diesel Blend." International Journal of Emerging Trends in Engineering and Development,Volume.1(January 2013) Issue 3/ January/ 2013/pp-2249-6149

[6] http://tyre-oil.blogspot.in/2010/07/nut-and-bolt-pyrolysis-of-tyre

[7] http://www.en.m.wikipedia.org/wiki/pyrolysis

[8] J.P.Hadiya, Internal Combustion Engines, Books India Publication 2013 